Original paper UDC: $1(045)$ Nietzsche, F.

doi: $10.21464 / \mathrm{sp} 36109$

Received: 23 August 2020

\title{
Sven Gellens, ${ }^{1}$ Benjamin Biebuyck ${ }^{2}$
}

Universiteit Gent, Blandijnberg 2, BE-9000 Gent

'sven.gellens@ugent.be, ${ }^{2}$ benjamin.biebuyck@ugent.be

\section{Natural Selection, Levelling, and Eternal Recurrence}

\author{
How Nietzsche Addressed Darwinism in \\ His Effort to Surpass the Body-Mind-Dichotomy
}

\begin{abstract}
This paper addresses the ongoing debate on Nietzsche's relationship to Darwinism, pursuing the specific meaning of Nietzsche's integrative account of evolution in his writings. Exploring the evolutionary vocabulary in his discussion of the will to power and his criticism of Malthus's concept of adaptation, the article claims that the so-called explicit Anti-Darwin position in Nietzsche's late writings is part of his encompassing attempt to surpass the narrow margins of a strictly anatomical-biological or socio-Darwinist concept of evolution. That Nietzsche does so by using biological vocabulary shows his eagerness to map the impact of biological and cultural forces on humankind's evolution. This article wants to put the contemporary debate on culture and evolution in a broader historical perspective. At the same time, it also wants to contribute to a better understanding of Nietzsche's philosophical anthropology, and in particular, of his changing ideas on weakness and strength, on the intellect and eternal recurrence as a principle of selection - ideas Nietzsche developed in his effort to surpass the traditional dichotomy of body and mind.
\end{abstract}

\section{Keywords}

evolution, Charles Darwin, Friedrich Wilhelm Nietzsche, eternal recurrence, will to power, body, adaptation, mind, selection

\section{Introduction}

Recent scholarship displays a growing consensus on the opinion that it is virtually impossible to read Nietzsche's writings without acknowledging what Richardson has called "a persisting awareness of the evolutionary scenario". ${ }^{1}$ Many critics, particularly in Anglo-American research, put Nietzsche next to Darwin or within Darwinism in a broader perspective. ${ }^{2}$ However, doing so,

John Richardson, "Nietzsche contra Darwin", Philosophy and Phenomenological Research 65 (2002) 3, pp. 537-575, here p. 538, doi: https://doi.org/10.1111/j.1933-1592.2002. $\underline{\text { tb00221.x. }}$.

2

Cf. Daniel R. Ahern, Nietzsche as Cultural Physician, Pennsylvania State University Press, University Park (PA) 1995; Keith Ansell-Pearson, Viroid Life. Perspectives on Nietzsche and the Transhuman Condition, Routledge, London - New York 1997; John Richardson, Nietzsche's New Darwinism, Oxford University Press, Oxford 2004; Gregory
Moore, Nietzsche, Biology and Metaphor, Cambridge University Press, Cambridge 2004; Gregory Moore, "Nietzsche and Evolutionary Theory", in: Keith Ansell-Pearson (ed.), A Companion to Nietzsche, Blackwell, Malden (MA) 2006, pp. 517-532; Dirk R. Johnson, "One Hundred Twenty-Two Years Later: Reassessing the Nietzsche-Darwin Relationship", The Journal of Nietzsche Studies 44 (2013) 2, pp. 342-353, doi: https://doi. org/10.5325/jnietstud.44.2.0342; Christian Emden, Nietzsche's Naturalism: Philosophy and the Life Sciences in the Nineteenth Century, Cambridge University Press, Cambridge 2014; Brian Leiter, "Nietzsche's Naturalism 
they measure his philosophy up to a project that is external to it - the project of Darwinism. Yet, Nietzsche's philosophical investigations display an intrinsic evolutionary paradigm. ${ }^{3} \mathrm{He}$ focuses on cultural development and aims to integrate biological and cultural forces in one encompassing account of evolution, even though, to do so, he uses biological vocabulary.

The evolutionary paradigm does not always centre, as Babich claims, upon "the Urkünstler or Aeon". ${ }^{4}$ It systematically entails the idea that transmission across generations, inheritance, does not occur on two separate levels, as traditional philosophical conceptualisations of the human as a creature that consists of a biological body and a cultural mind require, but through one single process - Einverleibung. ${ }^{5}$ In this article, we will show that Nietzsche's re-evaluation of the Darwinian theory of evolution was not a goal per se, but a stepping stone towards establishing his understanding of evolution through the framework of the will to power. This will help to understand why Nietzsche characterised his philosophical investigations into evolution in his late writings as "Anti-Darwin" (TI "Skirmishes" 14). Skowron has convincingly shown that Nietzsche's position cannot be seen as a rebuttal of Darwin, but rather - in the style of the ancient agon - as an affirmation of the famous biologist as an opponent. ${ }^{6}$ A close analysis of the Darwinian concepts in Nietzsche's writings will enable us to determine the exact meaning of this socalled Anti-Darwinism in his new philosophical understanding of the human. Hence, we will see that Nietzsche already addresses what has been labelled one of the major problems in contemporary biology ${ }^{7}$ and was described as "a deep evolutionary mystery on a par with the origins of life itself" ${ }^{8}$ - the question of cultural evolution.

\section{Natural Selection}

To better understand Nietzsche's evolutionary vocabulary, it is crucial to answer whether he endorses the principle of natural selection or not - an important issue in contemporary Nietzsche-research. Forber correctly claims that Nietzsche can only be considered a Darwinian if he accepts the principle of natural selection. To determine natural selection, Darwin formulated three prerequisites: (1) not all individuals can survive and reproduce (struggle for existence); (2) variation is necessary; and (3) the variation must be hereditary. ${ }^{9}$ Johnson argues that Nietzsche supported the idea of struggle for existence in general terms already in the Untimely Meditation on David Strauss (1873)..$^{10}$ In our view, Nietzsche articulated an explicit adherence to all three prerequisites of natural selection as early as in Menschliches, Allzumenschliches I (1878), be it with critical comments.

In aphorism 104 of Menschliches, Allzumenschliches I, entitled Self-Defence (Nothwehr), Nietzsche challenges the Malthusian hypothesis that limited resources have a selective effect on populations. The struggle for existence, he claims, is not entirely due to the availability of resources, but also goes back to pleasure (Lust):

"Without pleasure no life; the struggle for pleasure is the struggle for life." $(H H \mathrm{I}, 104)^{11}$

He defines pleasure as the "feeling of one's own power, of one's own strong excitation" (HH I 104). Whereas the Malthusian concept of struggle for existence operates on the level of an entire population, Nietzsche's somewhat enigmatic explanation indicates a shift to the level of the individual as the unit of 
selection. The struggle for existence not only depends on those organisms that are best adapted, but a variance also characterises it in disposition within each organism. This variance relies on the organism's degree of pleasure, which determines whether the organism obtains a favourable evolutionary position. Aphorism 104 thus explains what seemed to be a remark with casual evolu-

and Nineteenth-Century Biology", The Journal of Nietzsche Studies 48 (2017) 1, pp. 71-82, doi: https://doi.org/10.5325/jnietstud.48.1.0071.

3

See in particular: Werner Stegmaier, "Darwin, Darwinismus, Nietzsche. Zum Problem der Evolution", Nietzsche-Studien 16 (1987), pp. 264-287, here p. 269; Dirk R. Johnson, Nietzsche's Anti-Darwinism, Cambridge University Press, Cambridge 2010, p. 14, 135, who speaks of "creative antagonisms". Cf. also Babette Babich, "Nietzsche and/or/versus Darwin", Common Knowledge 20 (2014) 3, pp. 404-411, here p. 406, 410, doi: https:// doi.org/10.1215/0961754x-2732650.

4

B. Babich, "Nietzsche and/or/versus Darwin", p. 410 .

5

Sven Gellens, Benjamin Biebuyck, "The Mechanism of Cultural Evolution in Nietzsche's Genealogical Writings", Philosophy Today 56 (2012) 3, pp. 309-326, doi: https://doi.org/10.5840/philtoday201256313. Clark claims that Nietzsche is occupied with cultural inheritance by memes, and hence opposes Schacht's argument that Nietzsche supported a Lamarckian approach to the inheritance of biological characteristics. Cf. Richard Schacht, "Nietzsche and Lamarckism", The Journal of Nietzsche Studies 44 (2013) 2, pp. 264-281, here p. 270, doi https://doi.org/10.5325/inietstud.44.2.0264; Maudemarie Clark, "Nietzsche Was No Lamarckian", The Journal of Nietzsche Studies 44 (2013) 2, pp. 282-296, here p. 288, doi: https://doi.org/10.5325/jnietstud.44.2.0282. Forber, on the other hand, suggests that Nietzsche's teleological notion of will to power makes him into a Lamarckian in biological matters, whereas he is considered to be a Darwinian in cultural issues. Cf. Peter Forber, "Biological Inheritance and Cultural Evolution in Nietzsche's Genealogy", The Journal of Nietzsche Studies 44 (2013) 2, pp. 329341 , here p. 338 , doi: https://doi.org/10.5325/ jnietstud.44.2.0329.

Michael Skowron, "Nietzsches 'Anti-Darwinismus"”, Nietzsche-Studien 37 (2008) 1, pp. 160-195, here p. 175 , doi: https://doi.org/ 10.1515/9783110196900.1.160.
7

Francisco J. Ayala, "Human Evolution: The Three Grand Challenges of Human Biology", in: David Lee Hull, Michael Ruse (eds.), The Cambridge Companion to the Philosophy of Biology, Cambridge University Press, Cambridge 2008, pp. 233-255, here p. 234, 249

8

Peter J. Richerson, Robert Turner Boyd, Not by Genes Alone. How Culture Transformed Human Evolution, University of Chicago Press, Chicago 2005, p. 126.

Peter Forber, "Nietzsche was No Darwinian", Philosophy and Phenomenological Research LXXV (2007) 2, pp. 369-382, https://doi. org/10.1111/j.1933-1592.2007.00080.x; P. J.

Richerson, R. T. Boyd, Not by Genes Alone, p. 206.

\section{0}

"Nietzsche subscribed early on to Darwin's central notion that discrete biological wills struggle within nature ('struggle for existence') and that this struggle expressed an entirely this-worldly, immanent clash of wills." - D. R. Johnson, Nietzsche's Anti-Darwinism, p. 45; see also pp. 22-28); cf. in this matter also: B. Babich, "Nietzsche and/or/versus Darwin", p. 407

11

Translations of works by Nietzsche are taken from: Friedrich Nietzsche, The Gay Science. With a Prelude in German Rhymes and an Appendix of Songs, trans. Josephine Nauckhoff - Adrian Del Caro, Bernard Williams (ed.), Cambridge University Press, Cambridge 2001; Friedrich Nietzsche, Beyond Good and Evil. Prelude to a Philosophy of the Future, trans. Judith Norman, Rolf-Peter Horstmann Judith Norman (eds.), Cambridge University Press, Cambridge 2002; Friedrich Nietzsche, Writings from the Late Notebooks, trans. Kate Sturge, Rüdiger Bittner (ed.), Cambridge University Press, Cambridge 2003; Friedrich Nietzsche, The Anti-Christ, Ecce Homo, Twilight of the Idols, and Other Writings, trans. Judith Norman, Aaron Ridley - Judith Norman (eds.), Cambridge University Press, Cambridge 2005; Friedrich Nietzsche, $\mathrm{Hu}$ man, All Too Human. A Book for Free Spirits, trans. Reginald John Hollingdale, Cambridge University Press, Cambridge 2008; Friedrich Nietzsche, On the Genealogy of Morality, 
tionary connotations in aphorism 102, where Nietzsche criticises the claim that the morality of an action lies in the intention with which it is committed: "one desires pleasure or to ward off displeasure; it is always in some sense a matter of self-preservation" (HH I 102).$^{12}$ Here again, Nietzsche draws back on Darwinian vocabulary but infuses it with meanings linked with pleasure and power dynamics. Since he does not deny the functioning of the struggle for existence or its impact on the human organism, the young Nietzsche displays himself as a Darwinian with respect to the first prerequisite. However, he is a critical Darwinian, who re-evaluates the very idea of struggle for existence, not as a derivative of the Malthusian views on the shortage of resources, but of an individual's particular reactions of pleasure and displeasure to specific circumstances. ${ }^{13}$

In aphorism 224, Nietzsche adds that the Darwinian concept of struggle for existence (der berühmte Kampf um's Dasein) is not "the only theory by which the progress or strengthening of a man or a race can be explained" (HH I 224). ${ }^{14}$ Across the fifth chapter of the book, he mentions the two remaining necessary conditions of natural selection: variation and heritability. Variation occurs in the differentiation between the strong and the weak, two groups with a conspicuous internal variety. The process of habituation (Gewöhnung, $H H$ I 226) produces stronger people and compels them to be 'good' members of the community. By adopting the virtues and customs forced upon them, the stronger are more apt to respond to immediate challenges. Their (smaller) repertoire of possible responses enables them to choose conveniently. ${ }^{15}$ The weaker are described as people who liberated themselves from tradition (also see $H H$ I 225), who think more and can generate change in society, in particular - as Nietzsche emphasises - "intellectual" or "cultural" change (das geistige Fortschreiten, HH I 224). Heritability, finally, is enclosed in the explicit reference to "posterity" (Nachkommen, HH I 224) as a factor increasing the probability of their bringing about change in a community:

"It is the more unfettered, uncertain and morally weaker individuals upon whom spiritual progress depends in such communities: it is the men who attempt new things and, in general, many things. Countless numbers of this kind perish on account of their weakness without producing any very visible effect; but in general, and especially when they leave posterity, they effect a loosening up and from time to time inflict an injury on the stable element of a community."

The argument in aphorism 224 is incontestably situated within a Darwinian framework and thus supports our hypothesis that Nietzsche acknowledges a force in nature that can be labelled as natural selection: aphorisms such as this make it difficult to insist that Nietzsche rejected natural selection on the whole, and not only occasionally, as Richardson suggests. ${ }^{16}$

There has been much debate on natural selection in recent Nietzsche-research (e.g. Richardson, Moore, Johnson, Clark, Schacht), but to know whether Nietzsche accepted it or not, will not bring us to a full understanding of what evolutionary change means in his philosophical project. Crucial is how natural selection and specifically its operational impact on the organism is conceived. Nietzsche is highly critical of the exclusive impact of a struggle for existence on the individual because it renders the immediate environment a deterministic milieu. This could mean that there has to be a one-on-one relation between a trait and the state of the environment, making the organism a passive receptor of environmental changes. Nietzsche rejects this simplistic understanding of nature and proposes an alternative that explicitly tries to capture the intricate interaction between milieu and organism. Thus, he takes 
a decisive intellectual step towards a more integrated idea of humankind, characterised by a recursive interaction between the environment, the intellect and the body: the will to power.

One reason why Nietzsche will identify himself as "Anti-Darwin" in Götzen-Dämmerung - written ten years after the first volume of Menschliches, Allzumenschliches was published - is that he sees the Malthusian framework in which Darwinism operates as fundamentally reactive. ${ }^{17}$ To avoid this reactive framework, Nietzsche engages in a speculative discussion about nature by replacing the Malthusian emphasis on scarcity by one on profusion:

"[I]n nature it is not distress which rules, but rather abundance, squandering - even to the point of absurdity." (GS 349)

This rejection of Malthus is not irreconcilable with Darwinism. As we have seen, it is central to Darwin's thesis that variation is omnipresent in nature and not merely an exception. By interpreting nature as consisting of abundant variation Nietzsche drives the Darwinian focus on variation to its extreme. Denying Malthus does not imply the removal of the principle of selection. Since struggle is for Nietzsche the unique characteristic of the world ${ }^{18}$ selection will always take place. When Nietzsche replaces the Malthusian framework with that of the will to power, he in fact relocates the principle of natural selection. Yet, he does so in a typically nineteenth-century evolutionary fashion, i.e. in dialogue with authors such as Spencer ${ }^{19}$ and Lamarck. ${ }^{20}$

trans. Carol Diethe, Keith Ansell-Pearson (ed.), Cambridge University Press, Cambridge 2008; Friedrich Nietzsche, Daybreak. Thoughts on the Prejudices of Morality, trans. Reginald John Hollingdale, Maudemarie Clark - Brian Leiter (eds.), Cambridge University Press, Cambridge 2009.

\section{2}

We should note that in none of his writings Darwin identified self-preservation as nature's primary drive; at best, one can deduce it from his works. That Nietzsche linked Darwin consistently with self-preservation illustrates that he did not take notice from Darwin by means of primary sources - a philologist should have known better. When Nietzsche talks about self-preservation, this should not only be considered as something that consists out of "cunning and dissimulation", but also encompasses all that one does to preserve or protect oneself: “. .. one causes suffering, robs or kills, in order to preserve or protect oneself, to ward off personal harm; one lies when cunning and dissimulation is the proper means of self-preservation.” (HH I 104)

13

Cf. also KSA9:6[366], p. 291.

14

By translating Gesichtspunct as theory, the English version launches the idea that the struggle for existence is a closed theoretical construct per se, whereas Nietzsche calls it a "point of view", as we will show, within an encompassing theory of natural selection.

15

See also: "In the case of the individual human being, the task of education is to imbue him with such firmness and certainty he can no longer as a whole be in any way deflected from his path." (HH I 224)

16

J. Richardson, "Nietzsche contra Darwin", p.

546. For an in-depth discussion of this topic, see: R. Schacht, "Nietzsche and Lamarckism", pp. 264-281; and, more convincingly, M. Clark, "Nietzsche Was No Lamarckian", pp. 282-296. None of these authors takes, however, the concept of Einverleibung into consideration, as we will do.

17

Cf. TI "Skirmishes" 14. For Nietzsche's opposition against "reactive theories", see: Daniel Conway, "Life and self-overcoming", in: K. Ansell-Pearson (ed.), A Companion to Nietzsche, pp. 532-548.

18

Cf. $B G E$ 259; see also G. Moore, Nietzsche, Biology and Metaphor, pp. 37-38.

19

Marco Brusotti, Die Leidenschaft der Erkenntnis - Philosophie und ästhetische Lebensgestaltung bei Nietzsche von Morgenröthe bis 
Since adaptation is a consequence of natural selection, it may be useful to draw back on a distinction commonly made in contemporary biology. In the early 1980s, evolutionary biologists, such as Stephen Gould, questioned the notion of adaptation and suggested replacing the term re-adaptation by exaptation..$^{21}$ Exaptation describes the evolutionary process in which a trait serving one particular function comes to serve another or a trait that had no function becomes a new one. Daniel C. Dennett noticed that Gould was not the first to discuss the reorganisation of an organism to which this process leads, but Nietzsche. ${ }^{22}$ In the second essay of Zur Genealogie der Moral, Nietzsche states:

"The form is fluid, the 'meaning' even more so [...]. It is no different inside any individual organism: every time the whole grows appreciably, the 'meaning' of the individual organs shifts, - sometimes the partial destruction of organs, the reduction in their number (for example, by the destruction of intermediary parts) can be a sign of increasing vigour and perfection. To speak plainly: even the partial reduction in usefulness, decay and degeneration, loss of meaning and functional purpose, in short death, make up the conditions of true progressus: always appearing, as it does, in the form of the will and way to greater power and always emerging victorious at the cost of countless smaller forces." (GM II 12)

To understand this statement properly, we have to situate it against the background of the speculative discussion about Malthus. In this chapter, Nietzsche uses the concept of Sinnverschiebung (shift of sense, "Sinn" repeatedly put between quotation marks) and thus avoids the Malthusian semantics of Anpassung, except when he discusses it as the reactive adjustment of an organism to perturbations in its environment. Relocating the notion of natural selection within the framework of the will to power allows Nietzsche to differentiate between two processes of adaptation: one refers to the reorganisation of the organism as the result of a shift in the function of a certain trait (exaptation), the other denotes the better or lesser adjustment of an organism to its environment (adaptation). Both processes take place within a single mode of transmission and inheritance over the course of successive generations. Nietzsche makes this distinction explicit:

"[T]he pressure of this idiosyncrasy forces 'adaptation' into the foreground, which is a second-rate activity, just a reactivity, indeed life itself has been defined as an increasingly efficient inner adaptation to external circumstances (Herbert Spencer). But this is to misunderstand the essence of life, its will to power, we overlook the prime importance that the spontaneous, aggressive, expansive, re-interpreting, re-directing and formative forces have, which 'adaptation' follows only when they have had their effect; in the organism itself, the dominant role of these highest functionaries, in whom the life-will is active and manifests itself, is denied." (GM II 12)

In contemporary Darwinism, the concept of adaptation encompasses both Nietzsche's descriptions of adaptation as adjustment and as exaptation. However, to conclude from this - as Moore does ${ }^{23}$ - that Nietzsche rejects natural selection because he calls "adaptation" a second-order phenomenon, is not very convincing. Nevertheless, Moore is correct in noticing that Nietzsche goes beyond the contemporary understanding of exaptation and adaptation. Nietzsche points out that what we call exaptation does not just refer to the evolutionary process in which the actual use of a trait does not necessarily match the historical use for which it was selected by natural selection, but concerns the internal forces that structure how an organism participates in the environment - its instinctual organisation. Darwin labelled morphology to be the soul of biology, but in doing so, it reduced the organism's internal milieu. ${ }^{24}$ Nietzsche rectifies this reduction by determining the instinctual organisation of the organism as a crucial evolutionary factor. Hence, Nietzsche 
zealously advocates a "physio-psychology" ( $B G E 23)$ that encompasses morphology and psychology.

The primacy of exaptation over adaptation in Nietzsche's philosophy finds support in his consideration that all life forms appropriate "the alien and the weaker", making their reorganisation a crucial factor in evolution. In other words, the will to power sees all living beings as (maximally) manipulating their inner and outer environment:

"[L]ife itself is essentially a process of appropriating, injuring, overpowering the alien and the weaker, oppressing, being harsh, imposing your own form, incorporating, and at least, the very least, exploiting, - but what is the point of always using words that have been stamped with slanderous intentions from time immemorial? Even a body within which (as we presupposed earlier) particular individuals treat each other as equal (which happens in every healthy aristocracy): if this body is living and not dying, it will have to treat other bodies in just those ways that the individuals it contains refrain from treating each other. It will have to be the embodiment of will to power, it will want to grow, spread, grab, win dominance, - not out of any morality or immorality, but because it is alive, and because life is precisely will to power." (BGE 259)

The theory of the will to power prioritises appropriation, and not self-preservation, as nature's primary life force.$^{25}$ As was the case with adaptation, Nietzsche understands self-preservation as a second-order phenomenon, because it is a retraction of the primary tendency to manipulate the environment. ${ }^{26}$

Also sprach Zarathustra, De Gruyter, Berlin 1997, pp. 239-240.

20

G. Moore, Nietzsche, Biology and Metaphor, pp. 21-23; M. Clark, "Nietzsche Was No Lamarckian"; R. Schacht, "Nietzsche and Lamarckism".

21

Stephen J. Gould, Elisabeth S. Vrba, "Exaptation - a missing term in the science of form", Paleobiology 8 (1982) 1, pp. 4-15, doi: https://doi.org/10.1017/s0094837300004310.

\section{2}

When we interpret Nietzsche's self-reference "Anti-Darwin" as a straightforward rejection of Darwinism, we would have to come to the paradoxical conclusion that contemporary evolutionary biology is 'Anti-Darwin' itself. Yet, Dennett correctly observes: "Aside from Nietzsche's characteristic huffing and puffing about some power subduing and becoming master, this is pure Darwin. Or, as Gould might put it, all adaptations are exaptations, in cultural evolution as well as in biological evolution." - Daniel Clement Dennett, Darwin's Dangerous Idea: Evolution and the Meaning of Life, Penguin, London 1995, p. 465.

23

G. Moore, "Nietzsche and Evolutionary Theory", p. 520.

24

Charles Darwin, The origin of species, P. F. Collier, New York 1909, p. 472.
25

Nietzsche's references to exploitation as the primary function of everything alive is, contrary to what Ansell-Pearson claims (Viroid Life, pp. 105-106), not an expression of aristocratic radicalism - a term introduced in 1888 by one of Nietzsche's earliest critical commentators, the Danish philosopher Georg Brandes - but a different way of saying that the primary drive of life is appropriation. "〈Exploitation〉 does not belong to a corrupted or imperfect, primitive society: it belongs to the essence of being alive as a fundamental organic function; it is a result of genuine will to power, which is just the will of life. - Although this is an innovation at the level of theory, - at the level of reality, it is the primal fact of all history. Let us be honest with ourselves to this extent at least!" (BGE 259)

\section{6}

In this sense, we agree with Abel (Günter Abel, "Nietzsche contra 'Selbsterhaltung'; Steigerung der Macht und Ewige Wiederkehr", Nietzsche Studien 10 (1982) 1, pp. 367-384, doi: https://doi.org/10.1515/978311 0244304.367). Ahern correctly analyses Nietzsche's critical assessment of self-preservation as follows: "First, its impulse is not toward future growth via the other drives but toward an immediate stop to the haemorrhage of the body's strength. In short, its perspective is limited to mere stability. Second, it strives for stability through negating the most powerful drives." - D. R. Ahern, Nietzsche as Cultural Physician, pp. 23-24. 
"To wish to preserve oneself is a sign of distress, of a limitation of the truly basic life-instinct, which aims at the expansion of power and in so doing often enough risks and sacrifices self-preservation. [...] the struggle for survival is only an exception, a temporary restriction of the will to life; the great and small struggle revolves everywhere around preponderance, around growth and expansions, around power and in accordance with the will to power, which is simply the will to life." (GS 349)

Rolph's Biologische Probleme ${ }^{27}$ and Darwin's Malthusian interpretation of nature tempt Nietzsche to believe that in Darwinism self-preservation ( Selbsterhaltungstrieb) is the primary drive of an organism. Yet, Nietzsche does not reject the existence of self-preservation; rather he calls it one drive among others:

"Physiologists should think twice before positioning the drive for self-preservation as the cardinal drive of an organic being. Above all, a living thing wants to discharge its strength - life itself is will to power - self-preservation is only one of the indirect and most frequent consequences of this." $(B G E 13)$

Consequentially, Nietzsche calls self-preservation reactive and warns for its teleological implications. Seeing it as primary life-drive presupposes that the manifold parts of an organism can be united in its effort to survive and hence - in Hans Jonas's terms ${ }^{28}$ - the unity of form of the organism can be derived from the unity of its effort to survive: a presupposition Nietzsche explicitly denies. Instead, he maintains self-preservation as an aspect of his worldview of will to power, in which the organism is seen as an amalgam of conflicting powers and self-preservation is an instinct that overpowers other instincts. Nietzsche's discussion of self-preservation shows that the notion of fitness necessitates a redefinition as well.

The fitness of an organism cannot be claimed to be an exclusive effect of the morphology of the organism, rather it is an effect of its instinctual organisation. It is crucial to notice that this intellection allows Nietzsche to address another evolutionary force. The evolution of a human being or human 'races' is not determined by anatomical evolution alone but also involves the intellect. Going back to our original reading of Menschliches, Allzumenschliches I, this explains, as aphorism 224 showed, why the weaker foster progress:

"The strongest natures preserve the type, the weaker help it to evolve. [...] A people that becomes somewhere weak and fragile but is as a whole still strong and healthy is capable of absorbing the infection of the new and incorporating it to its own advantage." (HH I 224)

Nietzsche's line of thought corresponds to the views of heredity that had been circulating since the $1820 \mathrm{~s}$, in particular those developed by von Baer. ${ }^{29}$ Inconspicuous as it may be at first sight, he expands the modus operandi of natural selection to the cultural level. Humans evolve culturally when a community ${ }^{30}$ has a sufficiently strong corpus of beliefs (Glauben) and communal feeling (Gemeingefühl) that remains intact after individuals who do not adhere to all the common beliefs of the community - "degenerates" (entartende Naturen) - weaken the strong system of beliefs. When a community is open to these "partial weakenings" and can incorporate them, as to invigorate the system of beliefs, progress (Fortschreiten) is made possible. Nietzsche explains this progress as follows:

"Two things must come together: firstly the augmentation of the stabilising force through the union of minds in belief and communal feeling; then the possibility of the attainment of higher goals through the occurrence of degenerate natures and, as a consequence of them, partial weakenings and injurings of the stabilising force; it is precisely the weaker nature, as the tenderer and more refined, that makes any progress possible at all." (HH I 224) 
There is one more crucial instance, in which Nietzsche writes explicitly on natural selection from the point of view of an integrative understanding of the human. In The Antichrist, written in the fall of 1888, he claims that "pity runs counter to the law of development, which is the law of selection" $(A 7))^{31}$ Compassion is irreconcilable with evolution because it rescinds variation and counteracts selection. Since Nietzsche identifies the "law of the development" of life with "the law of selection", we can interpret the latter as the ultimate reference to natural selection in a discursive setting in which the difference between the biological and cultural level is abandoned.

We can conclude that Nietzsche takes up his Anti-Darwin position because he reads Darwinism as a reactive theory. ${ }^{32}$ However, this position is not gratuitous. Nietzsche opposes to and interacts with Darwinism in order to come to a better understanding of certain phenomena Darwinism claimed to have explained. Nietzsche's philosophy clings to its intrinsic evolutionary paradigm, one that aims at surpassing the traditional opposition between mind and body, by explicitly giving the intellect (Geist) a place, while "Darwin forgot about spirit" (TI "Skirmishes" 14). This emphasis on the importance of the intellect for evolution most clearly shows why Nietzsche considers himself to be Anti-Darwin in his later writings.

\section{The Intellect}

The interaction between humans and the environment and their impact on their own physical constitution encompasses both body and intellect, insofar as the intellect is orientated towards the world through the body. Nietzsche associates the intellect (Geist) with "caution, patience, cunning, disguise, great self-control, and everything involved in mimicry (which includes much of what is called virtue)" ( $T I$ "Skirmishes" 14). To describe the intellect, he uses

Cf. also B. Babich, "Nietzsche and/or/versus Darwin", p. 409.

\section{7}

Cf. G. Moore, Nietzsche, Biology and Metaphor, p. 37.

28

Hans Jonas, The Phenomenon of Life: Toward a Philosophical Biology, Northwestern University Press, Evanston (IL) 2001.

29

Ohad Parnes, "Es ist nicht das Individuum, sondern es ist die Generation, welche sich metamorphosiert.' Generationen als biologische und soziologische Einheiten in der Epistemologie der Vererbung im 19. Jahrhundert", in: Sigrid Weigel, Ohad Parnes, Ulrike Vedder (eds.), Generation: zur Genealogie des Konzepts - Konzepte von Genealogie, Fink, München - Paderborn 2005, pp. 235-259, here p. 235

30

In Jenseits von Gut und Böse, Nietzsche explains what he conceives of as "herds of people": "... racial groups, communities, tribes, folk, states, churches." (BGE 199)

\section{1}

Skowron ("Nietzsches "Anti-Darwinismus", p. 170) discusses this claim at length. Many scholars concluded that Nietzsche's refutation of the principle of selection in a social-Darwinist context means that he rejects the principle of natural selection altogether. There is a crucial difference between these two stances; ignoring this, makes it impossible to acknowledge the consistency of Nietzsche's thinking with regard to natural selection. Cf. Dirk R. Johnson, "Gattung", in: Paul van Tongeren, Gerd Schank, Herman Siemens (eds.), Nietzsche-Wörterbuch, De Gruyter, Berlin 2011.

32

Cf. Call's remark: "Nietzsche attacked Darwin and 'Darwinism' because he believed that these theories were manifestations of scientific nihilism." - Lewis Call, "Anti-Darwin, Anti-Spencer: Friedrich Nietzsche's critique of Darwin and 'Darwinism'", History of Science 36 (1998), pp. 1-22, here p. 4, doi: https://doi. org/10.1177/007327539803600101. 
vocabulary associated with weakness and physical restriction. Those who are bodily inapt to realise their goals will use their intellect (Geist) to do so:

"You have to need spirit in order to get it, - you lose it when you lose the need for it. Anyone with strength can do without spirit."

It seems that the intellect enables humans to compensate for their physical weaknesses; the weaker someone is, the more compelling the use of the intellect will be. Despite this compensatory capacity of the intellect Nietzsche ascribes it to the weak, and not to the strong. He interprets the intellect as a sign of weakness in the sense that whatever is produced by the intellect, indicates the inability of incorporating it into the body and making it instinctual:

"[C]omparatively speaking, humans are the biggest failures, the sickliest animals who have strayed the most dangerously far from their instincts - but of course and in spite of everything, the most interesting animals as well! [...] [W] see the development of consciousness, 'spirit', as a symptom of precisely the relative imperfection of the organism, as an experimenting, a groping, a mistaking, as an exertion that is sapping an unnecessarily large amount of strength away from the nervous system, - we deny that anything can be made perfect as long as it is still being made conscious." (A 14)

In Götzen-Dämmerung, Nietzsche attributes a greater degree of cleverness and cunning (List) to the common. The mediocre gain dominance over the exceptional by their greater numbers, ${ }^{33}$ but also because they are more dependent on the use of the intellect that allows them to dominate.

"[T]he weak keep gaining dominance over the strong, - there are more of them, and besides, they are cleverer $[\ldots]$. ." (TI "Skirmishes" 14)

As Nietzsche mentions in aphorism 116 of Die fröhliche Wissenschaft called "Herd Instinct", mediocre people are more cunning than the exceptional because they coerce the best-adapted humans by means of morality to "be a function of the herd and to ascribe value to [themselves] only as a function" (GS 116). The weak are more clever, Nietzsche claims, because education instrumentalises those who are educated in favour of the benefits of the herd and forces them to abandon their individuality. ${ }^{34}$ In aphorism 268 of Jenseits von Gut und Böse, Nietzsche relates the unfavourable position of the exceptional to their diminished reproductive attractiveness and their social isolation. ${ }^{35}$ The same line of reasoning occurs in aphorism 262 with respect to the mediocre, who adapt to cultural conventions:

"Only the mediocre have prospects for continuing on, for propagating - they are the people of the future, the only survivors: 'Be like them! Be mediocre!' is the only morality that still makes sense, that still finds ears." (BGE 262)

This shows that adaptation is not only due to forces present in the internal and external milieu of the individual, as was the case in Menschliches, Allzumenschliches, but is also explicitly shaped by a socio-cultural force: that of cultural levelling. Hence, it is crucial to note that Nietzsche's thoughts on the adaptation of organisms undergo a vital change in the eleven-year period between Menschliches, Allzumenschliches I and Götzen-Dämmerung. ${ }^{36}$ In the initial opposition, the powerful are strong and in the majority, the "tenderer and more refined" weak and outnumbered. The reversed antagonism in Götzen-Dämmerung (TI "Skirmishes" 14) opposes the common or mediocre to the exceptional, who encompass both those who are physically strong and those who are intellectually strong. This specification of the 'strong', which remains implicit in Götzen-Dämmerung, ${ }^{37}$ is made explicit in aphorism 57 of 
Der Antichrist, where Nietzsche distinguishes three types of humans. Some humans are more intellectually inclined, while others are more prone to address their physical powers. The third type is the mediocre, who is ubiquitous:

"In every healthy society, three mutually conditioning physiological types separate out and gravitate in different directions, each one having its own hygiene, its own area of work, its own feelings of perfection and field of mastery. Nature, not Manu, separates out predominantly spiritual people from people characterised by muscular and temperamental strength from a third group of people who are not distinguished in either way, the mediocre, - the latter being the great number, the first being the exceptions." ( $A$ 57)

That the mediocre, the herd, is superior in numbers to the exceptional, is congruent with the pyramidal concept of society Nietzsche unfolds in Der Antichrist. His aristocratism cannot be seen as a simple political preference; it is concerned with the shaping force of cultural evolution on the human organism. Nietzsche's discussion of caste-order and the identification of three human types are - heuristic - descriptions of the organisation of (human) life in a culturally shaped environment. For this reason, he admits that a higher culture requires mediocrity:

"Caste-order, order of rank, is just a formula for the supreme law of life itself, splitting off into three types is necessary for the preservation of society, to make the higher and highest types possible, - unequal rights are the condition for any rights at all. - A right is a privilege. Everyone finds his privilege in his own type of being. Let us not underestimate the privileges of the mediocre. Life becomes increasingly difficult the higher up you go, - it gets colder, there are more responsibilities. A high culture is a pyramid: it needs a broad base, its first presupposition is a strongly and healthily consolidated mediocrity. [...] It would be completely unworthy of a

33

See also aphorism 51 of Der Antichrist, where Nietzsche claims that the success of Christianity is not due to the increasing corruption of Roman nobility, but to the fact that Christians managed to outnumber the aristocrats.

34

"That is how education always proceeds: it tries to condition the individual through various attractions and advantages to adopt a way of thinking and behaving that, when it becomes a habit, drive and passion, will rule in him and over him against his ultimate advantage but for the "common good'." (GS 21)

\section{5}

"People who are more alike and ordinary have always been at an advantage; while people who are more exceptional, refined, rare, and difficult to understand will easily remain alone, prone to accidents in their isolation and rarely propagating." (BGE 268) See also aphorism 117 of Die fröhliche Wissenschaft, entitled "Herd pangs of conscience".

36

This shift, overlooked by Richardson ("Nietzsche contra Darwin", p. 570), implies that Nietzsche distances himself more and more from the von Baer point of view. Moore indicates that Nietzsche is in this period strongly engaged in reading Rolph (G. Moore, Nietzsche, Biology and Metaphor, p.
128). The change in his thinking may hence be due to his Rolph reading, but also to the influence of Féré, whose work Sensation et mouvement he had read in the Spring of 1888 (cf. Hans Erich Lampl, "Ex oblivione. Das Féré-Palimpsest", Nietzsche-Studien 15 (1986), pp. 225-264, doi: https://doi. org/10.1515/9783110244342.225; Bettina Wahrig-Schmidt, "'Irgendwie, jedenfalls physiologisch.' Friedrich Nietzsche, Alexander Herzen (fils) und Charles Féré 1888", Nietzsche-Studien 17 (1988), pp. 434-464). This hypothesis, of course, requires further investigation.

37

This can be deduced from one of the unpublished fragments (KSA 13:14[123], pp. 303-305), written in the spring of 1888 . Here, Nietzsche asserts that natural selection does not choose the strong and more complex and therefore more unstable - humans, but the weak, mediocre types who are more stable and durable: "In sum: the growth of the power of a species is perhaps guaranteed less by the prepondering of its favourites, its strongest members, than by the preponderance of the average and lower types [...]. In the latter is the great fruitfulness, duration; with the former comes growing danger, rapid devastation, speedy reduction in numbers." 
more profound spirit to have any objection to mediocrity as such. Mediocrity is needed before there can be exceptions: it is the condition for a high culture. When an exceptional person treats a mediocre one more delicately than he treats himself and his equals, this is not just courtesy of the heart, - it is his duty [...]." (A 57)

Nietzsche is so dismissive of the herd in his writings - up to the extent that he paradoxically pleads for the protection of the strong against the weak because it keeps gaining dominance over the strong, which is in his view a danger inherent in cultural evolution. Cultural development leads members of a community to become more base; while a community educates its members and develops their intellectual lives, this development can never go beyond what is beneficial for the community. Communities tend to diminish the variation of ideas in order to reinforce cultural levelling. ${ }^{38}$ But how does this happen?

\section{The Sociological Power of Cultural Evolution}

As we indicated, Nietzsche claims already in Menschliches, Alzumenschliches $I$ that both rekindling and stabilising forces allow for an accumulation of knowledge and, consequently, for society's development. Accumulation allows cultural adaptations to evolve from small variations, during a person's life, i.e. that person's Bildung, and over successive generations. In aphorism 361 of Die fröhliche Wissenschaft, Nietzsche states that transgenerational sedimentations of instincts generate different personalities. In aphorism 354 of the same book, he stresses the frailty of humans as animals and their need to communicate as an accumulative process across "entire races and lineages". ${ }^{39}$ For individuals, the formation of instincts is the result of both physio-psychological and sociological processes. Einverleibung (incorporation), Nietzsche claims, is such a never-ending integration of ideas, insights and possibilities into a knowing organism. In the human body, the layers of anatomical and cultural development are stratigraphically stacked upon each other, 'waiting' to be unearthed:

\footnotetext{
"The last three centuries very probably still continue to live on, in all their cultural colours and cultural refractions, close beside us: they want only to be discovered. In many families, indeed in individual men, the strata still lie neatly and clearly one on top of the other: elsewhere there are dislocations and faults which make understanding more difficult. A venerable specimen of very much older sensibility could certainly have been more easily preserved in remoter regions, in less travelled mountain valleys, in more self-enclosed communities [...]." (AOM 223; cf. also $G S$ 9)
}

Cultural evolution functions through what we today would call socialisation: the incorporation of societal norms by the individual. Nietzsche places this process within the encompassing view of cultural evolution because, from this perspective, communities themselves can be conceived of as units of selection. Hence, the necessity of a community to maximise the similarity between its constituents is to advance its own subsistence and prevent its disintegration. That cultural evolution operates through socialisation and accumulation becomes apparent in the issue of race.

In aphorism 44 of The Antichrist, Nietzsche explains that the "logical cynicism of a rabbi" is not a matter of personal inclination but race. The Jewish instinct of self-preservation, which principally wants "to use only those ideas, symbols, and attitudes that have been proven by the practice of the priests, the 
instinctual rejection of any other practice, any other perspective on what is valuable or useful", was brought to fruition by Christianity:

"The whole disaster was made possible only by the fact that a related, a racially related, type of megalomania already existed in the world, the Jewish type: as soon as the gap between Jew and Judaeo-Christian appeared, the latter had no choice except to use the same methods of self-preservation dictated by the Jewish instinct against the Jews themselves, while the Jews had only ever used them against non-Jews. The Christian is just a Jew with less rigorous beliefs." ( $A 44)$

This method of self-preservation, to which Nietzsche also refers as the "art of the holy lie", has nothing to do with the talents of an individual, but is made possible by accumulation over generations. Only as such could it be transformed from social learning (Tradition) into an instinct and thus become part of the human body: "that is not only tradition, it is endowment [Erbschaft]: only as endowment would it act like nature" ( $A 44)$. The explicit use of Erbschaft - which literally means inheritance, but usually is translated as endowment (as does Norman) - as opposed to tradition, emphasises the prerequisite of an accumulated process over generations. ${ }^{40}$ Socialisation and accumulation make attitudes, skills, beliefs, etc. into something corporeal, eventually forming a characteristic of a certain group of people (and as such a 'race'): "Hierzu gehört R a s s e." A race is for Nietzsche a group of people who have come to share "inner experiences" ( $B G E$ 268) and have accumulated common preferences over a long period of time.

"It is utterly impossible that a person might fail to have the qualities and propensities of his elders and ancestors in his body: however much appearances might speak against it. This is the problem of race." (BGE 264; cf. also BGE 268)

As Schank already noticed, "race" and "people" are therefore not reductive biological notions, but concepts in which cultural and biological forces merge. ${ }^{41}$

38

Cf. WS 267 .

39

See also aphorism 47 of Götzen-Dämmerung, where he explains expressions of beauty in a race or a family as "the final result of the accumulated labour of generations". Graceful gestures are no individual accomplishments, but require the accumulated incorporation of every stylisation of behaviour into the body. Good things are inherited; only by the process of Einverleibung they can be transformed from conscious manipulations of behaviour into spontaneous motions.

40

We agree that much can be said in favour of Norman's translation of Erbschaft as a cross-generational transfer of capital or of a gift. The context in which Nietzsche uses this term, however, clearly refers to cultural processes in terms of race, instincts and active accumulation across generations; hence, inheritance seems a more adequate translation to us.
41

“Das Wort 'Rasse' hat demnach bei Nietzsche, in den bisher interpretierten Texten, überwiegend die Bedeutung 'Volk', was auch daraus hervorgeht, dass Nietzsche oft die Wörter 'Rasse' und 'Volk' im gleichen Text nebeneinander verwendet. 'Volk' wird dabei als kulturell gewordene Einheit verstanden, die aber auch noch teilweise fehlen kann (so bei den Deutschen). Vorbilder sind die Griechen, Juden und Franzosen, die ihre Einheit (Griechen 'Schönheit, auch bei den Juden) 'erarbeitet' haben. Die Vorstellung einer 'reinen' genealogischen oder biologischen Basis im Sinn einer unvermischten Abstammung spielt dabei bei Nietzsche keine Rolle. Im Gegenteil: Völkermischung wirkt bereichernd und kann durch kulturelle 'Arbeit' ('sich nicht gehen lassen'), im oben erörterten Sinn einer 'Synthese', 'rein' werden." - Gerd Schank, "Rasse" und "Züchtung" bei Nietzsche, De Gruyter, Berlin 2000, p. 148. On this point, Nietzsche is clearly on a different track from Gobineau. 


\section{A Case-Study: Beyond Good and Evil, $\$ 262$}

This threat to cultural development is addressed as the case-study in paragraph 262 of Jenseits von Gut und Böse, where Nietzsche discusses the question of breeding an aristocratic community. He draws the readers' attention to a cultural evolutionary process parallel to what is now known as adaptive radiation, claiming that the emergences of cultures depend on the successful survival of groups in adverse ecological niches. Curtailing cultural variation among group members stabilises the group and thus engenders a "sturdy" type of human. Referring to a cultural group or community as a "species", Nietzsche reiterates the incorporation of cultural change into a model of biological evolution:

"A species originates, a type grows sturdy and strong, in the long struggle with essentially constant unfavorable conditions. Conversely, people know from the experience of breeders that species with overabundant diets and, in general, more than their share of protection and care, will immediately show a striking tendency towards variations of the type, and will be rich in wonders and monstrosities (including monstrous vices). You only need to see an aristocratic community (such as Venice or an ancient Greek polis) as an organisation that has been established, whether voluntarily or involuntarily, for the sake of breeding: the people living there together are self-reliant and want to see their species succeed, mainly because if they do not succeed they run a horrible risk of being eradicated. Here there are none of the advantages, excesses, and protections that are favorable to variation. The species needs itself to be a species, to be something that, by virtue of its very hardness, uniformity, and simplicity of form, can succeed and make itself persevere in constant struggle with its neighbors or with the oppressed who are or threaten to become rebellious." (BGE 262)

Reducing variation to one specific, successful type promotes qualities that will be advanced to the later generations as virtues. This accumulative breeding $^{42}$ of younger generations - "voluntarily or involuntarily" - gradually adapts individuals or groups to their environment. Educating a "sturdy" type hence is no longer experienced as necessary for survival, but it becomes "a form of luxury, [...] an archaic taste". Since the community no longer needs to struggle continuously with unfavourable conditions, the pace of cultural change turns "tropical", and cultural variation becomes abundant. This brings forth a whole new set of moralities and individuals:

\footnotetext{
"Variation, whether as deviation (into something higher, finer, rarer) or as degeneration and monstrosity, suddenly comes onto the scene in the greatest abundance and splendor; the individual dares to be individual and different. At these turning points of history, a magnificent, diverse, jungle-like growth and upward striving, a kind of tropical tempo in the competition to grow will appear alongside (and often mixed up and tangled together with) an immense destruction and self-destruction. This is due to the wild egoisms that are turned explosively against each other, that wrestle each other 'for sun and light,' and can no longer derive any limitation, restraint, or refuge from morality as it has existed so far. It was this very morality that accumulated the tremendous amount of force to put such a threatening tension into the bow: - and now it is, now it is being 'outlived'." (BGE 262)
}

The old morality provided an appropriate answer to unfavourable conditions in the past; "being outlived", it failed to provide successful answers to the changing conditions newer generations face. These generations, characterised by more cultural variation, were urged to provide new answers, new moralities. At such moments of transition in the development of a community, cultural accumulation engenders an expenditure of cultural variants, which Nietzsche designates as "das Genie der Rasse":

"The 'individual' is left standing there, forced to give himself laws, forced to rely on his own arts and wiles of self-preservation, self-enhancement, self-redemption. There is nothing but new 
whys and hows; there are no longer any shared formulas; misunderstanding is allied with disregard; decay, ruin, and the highest desires are horribly entwined; the genius of the race overflows from every cornucopia of good and bad; there is a disastrous simultaneity of spring and autumn, filled with new charms and veils that are well suited to the young, still unexhausted, still indefatigable corruption." (BGE 262)

This genius of the race, which expresses itself as an abundant eruption of creativity, threatens - and therefore rejuvenates - community stability. To control this threat, a conservative reflex sees to it that not the exceptional individuals, steering the future development of the community, thrive and multiply in these chaotic times, but rather the "mediocre":

"Danger has returned, the mother of morals, great danger, displaced onto the individual this time, onto the neighbor or friend, onto the street, onto your own child, onto your own heart, onto all of your own-most, secret-most wishes and wills: and the moral philosophers emerging at this time - what will they have to preach? These sharp observers and layabouts discover that everything is rapidly coming to an end, that everything around them is ruined and creates ruin, that nothing lasts as long as the day after tomorrow except one species of person, the hopelessly mediocre." (BGE 262)

In paragraph 268 Nietzsche further specifies why mediocrity forms a crucial social force, reinforced by humans' fragile nature and their urge to communicate (see also GS 354), stabilising the community's cultural landscape and levelling group members. This explains why the mediocre is the inherent danger to cultural evolution:

"Now, assuming that needs have only ever brought people together when they could somehow indicate similar requirements and similar experiences with similar signs, then it follows, on the whole, that the easy communicability of needs (which ultimately means having only average and base experiences) must have been the most forceful of the forces that have controlled people so far. People who are more alike and ordinary have always been at an advantage; while people who are more exceptional, refined, rare, and difficult to understand will easily remain alone, prone to accidents in their isolation and rarely propagating. Immense countervailing forces will have to be called upon in order to cross this natural, all-too-natural progressus in simile, people becoming increasingly similar, ordinary, average, herd-like, - increasingly base!" (BGE 268)

This intrinsic tendency of cultural evolution to make the members of a cultural group more similar, base and herd-like finds its expression in the democratic tendencies of nineteenth-century European states. When Nietzsche calls "the democratic movement [...] the heir to Christianity" (BGE 202) it is exactly to denote the process of levelling that lies at the heart of the socialist and Christian calls for equality of all, and should not be ascribed exclusively to Nietzsche's political disparagement of any mass-movement:

"We who have a different faith -, we who consider the democratic movement to be not merely an abased form of political organisation, but rather an abased (more specifically a diminished) form of humanity, a mediocritization and depreciation of humanity in value: where do we need to reach with our hopes?" (BGE 203)

42

See also paragraph 188 of Jenseits von Gut und Böse, which explains morality as a form of long-term compulsion. See also Schank's claim that "Nietzsche uses Darwinian terms, such as 'selection', [...] with a new metaphorical meaning": "the word 'Züchtung' in Nietzsche's usage means 'education', not biological breeding". - Gerd Schank, "Race and Breeding in Nietzsche's Philosophy", in:
Nicholas Martin (ed.), Nietzsche and the German Tradition, Lang, Frankfurt on the Main 2003, pp. 237-244, here p. 243. Schank's explanation confirms our hypothesis that Nietzsche incorporates cultural development into a model of biological evolution; the use of "new metaphorical meanings" hence cannot be understood as a rejection of natural selection, but rather as its reinforcement. 
This insight into the basic tendency of cultural evolution to 'mediocritise', combined with the perception that cultural evolution can influence the organism at a much faster rate than natural selection, incites Nietzsche to counter that tendency with "immense countervailing forces" (BGE 268) and urges for a re-evaluation of all values. This line of reasoning reaches a climax in paragraph 203, which concludes the fifth part of Jenseits, "On the Natural History of Morals", and reads as follows:

"Towards new philosophers, there is no alternative; towards spirits who are strong and original enough to give impetus to opposed valuations and initiate a revaluation and reversal of 'eternal values'; towards those sent out ahead; towards the men of the future who in the present tie the knots and gather the force that compels the will of millennia into new channels. To teach humanity its future as its will, as dependent on a human will, to prepare for the great risk and wholesale attempt at breeding and cultivation and so to put an end to the gruesome rule of chance and nonsense that has passed for 'history' so far (the nonsense of the 'greatest number' is only its latest form): a new type of philosopher and commander will be needed for this some day, and whatever hidden, dreadful, or benevolent spirits have existed on earth will pale into insignificance beside the image of this type." (BGE 203)

Such 'immense forces' can be found in the 'thought' of eternal recurrence.

\section{Eternal Recurrence}

Nietzsche's enigmatic concept of eternal recurrence (ewige Wiederkunft) is not often the centre of attention when his Anti-Darwinian perspective is being discussed. Then again, understanding the role of culture and intellect in evolution helps us to appreciate the magnitude Nietzsche ascribed to the idea of eternal recurrence. It appears most clearly in the famous aphorism 341 of Die fröhliche Wissenschaft. Nietzsche presents it as a correlate to amor fati, the unremitting affirmation of life, and spells it out as an existential experiment:

"If this thought gained power over you, as you are it would transform and possibly crush you; the question in each and every thing, 'Do you want this again and innumerable times again?' would lie on your actions as the heaviest weight! Or how well disposed would you have to become to yourself and to life to long for nothing more fervently than for this ultimate eternal confirmation and seal?" (GS 341)

At first sight, the demon's question seems to be quite modest, but both in the aphorism itself and in later resonances of it, Nietzsche frames it as the heaviest of all questions. The prophetical allure of the question indicates that the issue of eternal recurrence may well be one of the "immense countervailing measures" ( $B G E 268)$ with which Nietzsche hopes to counteract the process of making human beings more base. Central to this issue is the possibility of incorporating the idea: those who consider it, have to be "well disposed" to bear its weight, and when they do so, the idea will "transform" them. Hence, it selects those who are healthy and strong enough - exceptional people and, as such, it is supposed to annul the negative effects of the old ethical principle that Nietzsche calls, with reference to Schopenhauer ("the philosopher's stone, sought for millennia", KSA 11:26[85], p. 172), the laede-neminem-morals, for which the highest moral value is to do no harm to anyone ( $B G E$ 186). Incorporating eternal recurrence protects the exceptional against the cunning and greater cleverness of the weak, by means of which they gain persistent dominance over the strong, and against ideas that may cause degeneration. Christian virtues such as compassion interfere with natural selection, 
because "[t]hey have preserved too much of what should be destroyed" ( $B G E$ 62). ${ }^{43}$ Nietzsche resumes this criticism in Der Antichrist:

"The mortal dangers of pity will be much more apparent if you measure pity according to the value of the reactions it tends to produce. By and large, pity runs counter to the law of development, which is the law of selection. Pity preserves things that are ripe for decline, it defends things that have been disowned and condemned by life, and it gives a depressive and questionable character to life itself by keeping alive an abundance of failures of every type. People have dared to call pity a virtue ( - in every noble morality it is considered a weakness -$)$ [...]." $(A 7)$

Eternal recurrence prevents the process of degradation because it is a selective idea (KSA 11:25[227], p. 73): in an unpublished - and unpolished - fragment Nietzsche claims that those who do not believe in eternal recurrence will eventually become extinct (KSA 9:11[338], p. 573). ${ }^{44}$ Ansell-Pearson assumes that this principle of selection, which operates on the cultural level, replaces natural selection:

"If man is the product of natural selection, the overman - considered as the future of evolution - will be the invention of a wholly different kind, and it is in the context of Nietzsche's engagement with Darwin that we can perhaps best understand his positing of the eternal return as promoting an alternative principle of selection to be placed in the service 'of strength (and barbarism!!)'." 45

Now we can understand why this is not the case - on the contrary. The principle of selection on the cultural level serves to secure the operativeness and the efficacy of natural selection - understood within the framework of the will to power. Hence, it is no "alternative principle", but it is necessary complement: it keeps natural selection itself 'sound'. Skowron has already made this point: eternal recurrence has, he explains,

“... memetische Züge kultureller Entwicklung [...und] gehört [...] auch der natürlichen Entwicklung an [...]. Sie liefert nicht nur eine Alternative zur Evolution, die sie zugleich einschließt, sondern auch zu deren Gesetz der Selektion, sofern sie nicht mehr selektierend die Wiederkunft aller Dinge will." ${ }^{46}$

However, Skowron draws the wrong conclusion: eternal recurrence is not Anti-Darwinian, he claims, because it gives up the practice of selection in order to establish a practice of complete affirmation. ${ }^{47}$ As Nietzsche emphasises in the unpublished fragment mentioned before (KSA11:25[227]), it is "the great breeding thought". In yet another unpublished fragment (KSA9:11[220], pp. 526-527) we can find Nietzsche referring to the "transformative" (umbildend) potential of the idea of eternal recurrence; it is the "most powerful idea", as

43

See also $B G E 62$ on the complicity of Christian values in the "deterioration of the European race".

44

Earlier in the same notebook, Nietzsche reflects on the "slow process of selection" and the ways in which the individual can surpass this (KSA 9:11[43], p. 457). This underlines the importance of the evolutionary context in which the concept of eternal recurrence functions and is overlooked entirely by e.g. Deleuze: “... the extreme forms return - those which, large or small, are deployed within the limit and extend to the limit of their power, transforming themselves and changing one into another. Only the extreme, the excessive, returns; that which passes into something else and becomes identical." - Gilles Deleuze, Difference and Repetition, trans. Paul Patton, Athlone, London - New York 2004, p. 51.

45

K. Ansell-Pearson, Viroid Life, p. 101.

46

M. Skowron, "Nietzsches 'Anti-Darwinismus"," p. 192.

47

Ibid., p. 193. 
it is able to redetermine and reorganise an individual's affects. ${ }^{48}$ Again, in a letter to Franz Overbeck from 8 March 1884, he describes the eternal return as a thought that can change everything and revalue all values, when only it is believed to be true. Once the idea has become part of the lives of individuals and this over successive generations, it can eventually get incorporated into the body as an instinct. ${ }^{49}$ The goal of the idea of eternal return is to transform contemporary man in a healthy organism by countering life-denying ideas, because it does not castrate the body of the instincts - as, according to Nietzsche, Christian ideas do. ${ }^{50}$

\section{Conclusion}

We hope to have shown that Nietzsche's motive for calling his position Anti-Darwin is actually a Darwinian understanding of cultural evolution - not in the common sense of the word, but in its enriched meaning, surpassing the traditional mind-body-dichotomy. In his philosophical investigations on evolution, Nietzsche understands human beings as organisms capable of culture, who have a recursive influence on their own physical constitution. The intellect makes humans more responsive to environmental perturbations and enhances their survival rate. The laede-neminem-morals - in particular European Christianity - are determined by Nietzsche as the cultural formations most responsible for the increasing imbalance between physiology and culture throughout history. ${ }^{51}$ They one-sidedly advocate the development of the intellect over the body - a process Nietzsche tries to counteract with his philosophy of eternal recurrence. The re-evaluation of values brought about by eternal recurrence has to restore the evolutionary dynamic of body and culture. Labelling himself an Anti-Darwinian for these reasons and aptly pointing to levelling as the inherent danger of cultural evolution, he ironically caused only greater confusion among his contemporary and future readers as we witness until today. Nietzsche was not simply criticising Darwinism, rather he was trying to tackle the questions it left unanswered.

\section{Sven Gellens, Benjamin Biebuyck}

\section{Prirodna selekcija, poravnanje i vječno vraćanje istog}

\section{Kako se Nietzsche dotiče darvinizma u svom}

nastojanju da nadiđe dihotomiju uma i tijela

\footnotetext{
Sažetak

Ovaj se rad bavi aktualnom raspravom o Nietzscheovoj vezi s darvinizmom, usmjeren na posebno značenje Nietzscheova integrativnog razmatranja evolucije u njegovim spisima. Istražujući rječnik evolucije u njegovim raspravama o volji za moć i kriticizmu Malthusova pojma prilagodbe, radom se tvrdi da je takozvana anti-darvinistička pozicija u Nietzscheovim kasnim spisima dio njegova obuhvatnog pokušaja da nadiđe uske granice strogo anatomskobiološkog ili društveno-darvinističkog pojma evolucije. Da Nietzsche to čini služeći se biologijskim rječnikom pokazuje njegova revnost u kartiranju utjecaja bioloških i kulturnih sila na ljudsku evoluciju. Radom se aktualna rasprava o kulturi $i$ evoluciji želi smjestiti u širu povijesnu perspektivu. Istovremeno, želi doprinijeti i boljem razumijevanju Nietzscheove filozofijske antropologije, a posebno, njegove mijenjajuće ideje o slabosti i snazi, o intelektu $i$ vječnom vraćanju istoga kao principu selekcije - ideje koje je Nietzsche razvio u nastojanju da nadide tradicionalnu podjelu tijela i uma.
} 


\title{
Ključne riječi
}

evolucija, Charles Darwin, Friedrich Wilhelm Nietzsche, vječno vraćanje istog, volja za moć, tijelo, prilagodba, um, izbor

\section{Sven Gellens, Benjamin Biebuyck}

\section{Natürliche Selektion, Ausgleichung und \\ die ewige Wiederkunft des Gleichen}

Wie Nietzsche den Darwinismus anschneidet, in seinem Bestreben, die Dichotomie von Geist und Körper zu überwinden

\begin{abstract}
Zusammenfassung
Diese Arbeit setzt sich mit der gegenwärtigen Diskussion über Nietzsches Verbindung zum Darwinismus auseinander und konzentriert sich auf die besondere Bedeutung von Nietzsches integrativer Betrachtung der Evolution in seinen Schriften. Indem man den Wortbestand zur Evolution in seinen Erörterungen über den Willen zur Macht und den Kritizismus im Hinblick auf Malthus' Anpassungsbegriff erforscht, argumentiert man mit diesem Aufsatz, dass die sogenannte antidarwinistische Position in Nietzsches späteren Schriften Teil seines eingehenden Bemühens ist, den engen Rahmen eines streng anatomisch-biologischen oder sozialdarwinistischen Begriffs der Evolution zu sprengen. Dass Nietzsche dies mithilfe der biologischen Lexik tut, offenbart seinen Eifer, den Einfluss biologischer und kultureller Kräfte auf die menschliche Evolution zu kartieren. Der Beitrag versucht, die aktuelle Debatte über Kultur und Evolution in eine breitere historische Perspektive hineinzuversetzen. Gleichlaufend möchte man zu einer besseren Auslegung von Nietzsches philosophischer Anthropologie und insbesondere von seiner sich verändernden Vorstellung von Schwäche und Stärke, vom Intellekt und einer ewigen Wiederkunft des Gleichen als Prinzip der Selektion beisteuern - Ideen, die Nietzsche entfaltet hat, im Bestreben, die traditionelle Trennung von Körper und Geist zu überwinden.
\end{abstract}

\section{Schlüsselwörter}

Evolution, Charles Darwin, Friedrich Wilhelm Nietzsche, ewige Wiederkunft des Gleichen, der Wille zur Macht, Körper, Anpassung, Geist, Wahl

\section{Sven Gellens, Benjamin Biebuyck}

\section{La sélection naturelle, l'alignement et l'éternelle retour du même}

\author{
Comment Nietzsche touche au darwinisme dans ses \\ efforts pour dépasser la dichotomie entre l'esprit et le corps
}

\begin{abstract}
Résumé
Ce travail traite de la discussion actuelle sur la relation de Nietzsche avec le darwinisme, en se concentrant sur les considérations intégratives nietzschéennes de l'évolution dans
\end{abstract}

48

Also see: "Wenn du dir den Gedanken der Gedanken einverleibst, so wird er dich verwandeln. Die Frage bei allem, was du thun willst: «ist es so, daß ich es unzählige Male thun will?〉 ist das größte Schwergewicht." (KSA 9:11[143], p. 496)

49

See also KSA 9:11[158], p. 503 and KSA $9: 11[320]$, p. 565. For a more extensive discussion of this topic see: S. Gellens, M.
Biebuyck, "The mechanism of cultural evolution in Nietzsche's genealogical writings".

50

Cf.: "To have to fight the instincts - that is a formula for decadence: as long as life is ascending, happiness is equal to instinct." (TI II 11)

51

See also aphorisms 3 and 62 of Der Antichrist. 
ses écrits. Recherchant le vocabulaire de l'évolution dans ses discussions sur la volonté de puissance et dans la critique du concept malthusien de l'adaptation, ce travail affirme que ladite position anti-darwiniste dans les écrits tardifs nietzschéens constitue un élément de sa tentative d'ensemble de dépasser les limites du concept d'évolution strictement biologico-anatomique ou du darwinisme social. Que Nietzsche s'y applique en se servant du vocabulaire biologique montre son zèle pour représenter l'influence des forces biologiques et culturelles sur l'évolution humaine. À travers ce travail, la discussion actuelle sur la culture et l'évolution est située dans une perspective historique plus large. En même temps, ce travail souhaite aussi contribuer à une compréhension plus exhaustive de la philosophie anthropologique de Nietzsche, et particulièrement, de ses idées changeantes sur la faiblesse et la force, sur l'intellect et l'éternel retour du même comme principes de sélection - idées que Nietzsche a développées dans ses efforts pour dépasser la séparation traditionnelle du corps et de l'esprit.

\section{Mots-clés}

évolution, Charles Darwin, Friedrich Wilhelm Nietzsche, éternel retour du même, volonté de puissance, corps, adaptation, esprit, choix 